\title{
RESTRICTION ANALYSIS: AN APPLIED VIEW IN A PUBLIC EDUCATIONAL INSTITUTION OF THE RIO GRANDE DO SUL
}

\author{
Lavinia Lopes de Mello \\ Universidade de Santa Cruz do Sul, Brazil \\ E-mail: lavinia97@hotmail.com \\ Débora Desconsi Sutero \\ Universidade Franciscana, Brazil \\ E-mail: deborasutero@hotmail.com \\ Luis Carlos Alves da Silva \\ Universidade de Santa Cruz do Sul, Brazil \\ E-mail: luiscarlosalves0207@gmail.com \\ Maicon da Silva \\ Universidade de Santa Cruz do Sul, Brazil \\ E-mail:maicon213@bol.com.br \\ Fernando Batista Bandeira da Fontoura \\ Universidade de Santa Cruz do Sul, Brazil \\ E-mail: fbfontoura@unisc.br \\ Submission: $7 / 25 / 2020$ \\ Revision: 8/4/2020 \\ Accept: 8/20/2020
}

\section{ABSTRACT}

This study aims to analyze the applicability of the five steps of the theory of restrictions as an alternative for improving the efficiency of processes in a public organization. Methodologically the study is characterized as descriptive and exploratory, with bibliographic research and data analysis being performed qualitatively. The research was carried out in loco, through the observation technique. As main results of the research, the feasibility and importance of the application of the tool is ratified, directly impacting on efficiency and quality maximization in the services offered to society and optimizing public resources, which can be applied in other sectors of our society. With the efficiency in achieving the applicability of the five steps of the theory of restrictions, the management and identification of the bottleneck in the process of cooperation agreements contributed to speed up public service. The research becomes relevant since it encourages the application of the theory of restrictions in public entities, being a tool for identifying restrictions in processes, providing greater 
DOI: 10.14807/ijmp.v12i4.1396

protection against human weaknesses and also reducing the possibility of errors and irregularities, demonstrating care with public resources to the population and applying them efficiently.

Keywords: Teory of Restrictions; Public Organization; Public Administration; Management.

\section{INTRODUCTION}

The Theory of Restrictions (TOC) is a methodology applied to identify limiting factors, which refer to restriction, directly impacting the execution of an objective. This theory can be applied in public or private organizations, provided that the limitations of processes are measured and it is also an important tool for planning results (Bornia, 2010; Fontoura, 2013; Fontoura \& Pozzebon, 2016).

Thus, public organizations inserted in a new governmental scenario are increasingly susceptible to budget cuts and blockades, in addition to bureaucratic processes and cast structures, which prevent efficiency in achieving their goals. Therefore, the evaluation of the performance of public entities regarding transparency, computerization and accountability currently has a greater demand for society, although the improvement in the management of organizations is still a challenge for the Public Administration.

In this sense, the TOC methodology can contribute to the restrictive identification, through the application of five steps of the process of focusing on TOC in the process of Cooperation Agreements in a Public Institution in the area of Education. On the other hand, it is necessary that these entities develop alternative actions, identifying bottlenecks that prevent the efficient execution of services.

The theory of restrictions assumes that every entity has a restriction that limits the performance of its activities in achieving its goals, considering that the main goal of every company is profitability and that if there were no limitations the gains would be infinite (Gibbon, Gonçalves \& Rodrigues, 2008). According to the authors, this is explained by the fact that the use of OCD values the overall result to the detriment of the parties' results, emphasizing the restrictions that are the obstacles of the system, so that they will not harm the overall profitability of the company and the achievement of its goals.

In addition, TOC presents itself as an alternative for implementing improvements in the system, in which it simplifies costs and directs the organization to its path, the goal, which is profit (Goldratt \& Cox, 1993). Based on the initial assumptions of the theme of this study, an analysis was carried out in correlated studies published in public entities for references and to 
DOI: 10.14807/ijmp.v12i4.1396

present the applicability in the sector, in order to provide better quality of services and efficiency of public administration, being identified the following studies: Management of Restrictions in Public Health Organizations: A Process of Continuous Improvement, by Sabbadini, Gonçalves and Oliveira (2006) and "The Contribution of the Theory of Restrictions to the Procurement Process of Military Organizations of the Brazilian Army", by Luchi (2006).

Therefore, this study aims to answer the following research question: How to analyze the five steps of implementing restrictive factors in a public organization? This article aims to analyze the applicability of the five steps of the theory of restrictions as an alternative to improve the efficiency of processes in a public organization.

The relevance of this study is justified, through the contribution of TOC as a theory of business management, as the detection of the constraints of a productive system depends greatly on the characteristics of each type of segment. This study reinforces the importance of the application of the five steps of TOC in a Public Institution in the area of Education, in which a limited amount of studies related to the public area is presented, which demonstrates the thinking of methodologies aimed at the effectiveness of public management.

Having said that, this article was organized as follows: the first part refers to this introduction. The following section deals with the theoretical synthesis on the theme and its contextualization's. In section 3 (three) the research methodology is presented. The results are explained, analyzed and discussed in section 4 (four). Finally, the last part addresses the final considerations, which aim to indicate new research possibilities.

\section{THEORETICAL FOUNDATION}

Through the conceptualization, we will seek evidence, in this chapter, the view of different authors and legislations on the subject of this research, and that, later, will serve to support the analysis of the results and final considerations.

\subsection{Theory of Restrictions (TOC)}

The theory of restrictions (TOC) emerges as a management model that considers any manageable system to be limited in achieving more than its goals by a very small number of constraints, which prevent organizations from achieving a better level of performance, therefore, they must be identified and managed to increase the operational result, generating a process of continuous improvement. 
INDEPENDENT JOURNAL OF MANAGEMENT \& PRODUCTION (IJM\&P)

http://www.ijmp.jor.br

v. 12, n. 4, May-June 2021

ISSN: 2236-269X

DOI: 10.14807/ijmp.v12i4.1396

This theory began when Dr. Eliyahu Goldratt, an Israeli physicist, was asked to design a production programming system for a friend's chicken coop plant (Sipper \& Bulfin, 1997). Already in the 80 's, the system was improved, through it developed a software for use in optimized production environments, this is now marketed under the name of OPT, Optimized Production Technology.

While the software system was developing and undergoing improvements in the productive environments of organizations, OPT began to develop the OPT management strategy and its rules, which evolved, towards a more complete and robust management analysis, going on to work with cost reduction, which later came to be known as TOC.

The evolutionary process of TOC, at times faced many barriers, especially the cultural ones that existed in organizations, in this context Goldratt was motivated to write the book ("The Goal"), in which are presented the principles of the theory developed, and its main focus, which was to identify production bottlenecks that can generate inefficiency throughout the process limiting it as a whole in an organization (Goldratt \& Cox, 1990). In Brazil, the theory of restrictions began to be introduced in 1984, with the translation of the book into Portuguese.

The TOC assumes that every organization has a restriction that limits the performance of its activities in achieving its goals, given that the main goal of a private organization is profitability and that, if there were no limitations, the gains would be infinite.

The idea of the theory of restrictions focused on restriction as the main point to be analyzed in the industrial, administrative, purchasing, logistics environment, among other processes, as in this essay the application for public sector activities (Cox \& Schleier, 2013).

From the understanding that in some period of time at least a restriction that limits the performance of a system in relation to the achievement of its results, can happen in an organization whether private or public, understand the steps of the five processes that TOC provides, can improve the performance of the system with identification of the restriction.

In this context, the five steps for the continuous improvement of the process by TOC (Noreen, Smith \& Mackey, 1996):

a) Identify the restriction of the system. Constraints must be identified because they determine the flow of the system. In a well-managed organization, the restrictions are easy to find; 
DOI: $10.14807 /$ ijmp.v12i4.1396

b) exploit system constraints. After identifying the constraint in the system it should be optimized to make the system more efficient and increase the resource capacity rate;

c) Subordinate all other resources to the restriction. This step consists of making all other activities subject to restriction;

d) Lift restrictions. The organization should seek to relax the restriction, which means in some way increasing its production capacity;

e) Return to the first step if a constraint is elevated and does not let inertia be more of a system constraint;

The five measures presented have as main factor the gain. Maximizing this gain is the main premise of the theory of constraints, in contrast to the traditional theoretical framework aimed at reducing costs. As there is always a restriction in the system, it seeks to eliminate it in order to increase the gain of production and efficiency in activities coordinated by the public and private sectors.

According to Goldratt and Cox (2003), it is important that, after these five steps, if the productive capacities have been changed and the restriction has already been remedied, the whole system is revised so that the inertia itself does not take over the system and becomes a restriction, thus ensuring the improvement in the process.

By analyzing the five steps of the TOC, in a public or private organization, the manager is applying a methodology that allows the identification of failures in the processes, enabling the management of activities and the search for efficiency, and can also develop appropriate management accounting tools to support decisions that involve the management of these processes.

\subsection{Accounting Applied to the Public Sector}

Accounting in public activity is based on Law 4,320 of March 17, 1964, in which it established the general rules of financial law for the preparation and control of budgets and balance sheets of the union, states, municipalities and the Federal District, in which it cites, "the accounting will show before the public treasury the situation of all those, in any case, collect revenue, make expenses, manage or store assets owned or entrusted to it”.

In addition, Brazilian accounting standards (NBC) also present public accounting as the science that performs the information-generating process guided by the set of principles and 
INDEPENDENT JOURNAL OF MANAGEMENT \& PRODUCTION (IJM\&P)

http://www.ijmp.jor.br

v. 12, n. 4, May-June 2021

ISSN: 2236-269X

DOI: $10.14807 /$ ijmp.v12i4.1396

norms that direct the control of the assets of public entities, providing users with budgetary, financial and economic information, and decisions and projections for the coming periods (NBC 16.1, 2013).

Also according to NBC 16.1, (2013), the field of application of accounting applied to the public sector covers all entities that make up the sector, observing the standards and techniques of accounting applied to public sectors, considering the following scope: (a) fully, government entities, social services and professional councils; (b) partially, the other entities of the public sector, to ensure sufficient procedures for accountability and instrumentalization of social control.

According to the accounting manual applied to the public sector (MCASP) (2014), it has as its main objective the provision of services to society, unlike private companies that aim at profit. In addition, it also presents that these entities are differentiated from other entities considering that their revenue collected is basically composed of taxes and contributions, due to the importance of the public budget required by legislation, long-term programs, and supervision of society in the management of these companies.

Accounting is considered as a key piece assisting in budget execution, providing the public manager with a detailed analysis of data, being considered an important tool in the decision-making process, demonstrating the positive and negative effects of administrative acts related to the budget and measuring possible restrictions that may cause inefficiency to achieve the stipulated goals.

Given the importance of accounting for public management, among the various accounting tools that can be applied, we will work with the application of the five steps of the theory of restrictions (TOC) continuously, in order to identify the possible restrictions for the provision of services in the public sector, using this information to improve the performance of the areas involved.

According to Kohama, (2014), the public sector needs to efficiently control all its operations, providing greater protection against human weaknesses and also reducing the possibility of errors and irregularities, demonstrating care for resources and applying them efficiently. Thus, with the application of the five steps of the TOC, public managers will no longer rely solely and exclusively on traditional cost calculation patterns, arising from expenses of tangible and intangible assets, reducing the risk of analyzing incorrect variables and making decisions that can generate some kind of financial risk. 
DOI: 10.14807/ijmp.v12i4.1396

The application of TOC theory is not something common, but it needs to function as a flow, where each department corresponds to a link, interconnected with all areas, generating an exchange of information with each other. However, each department needs to perform its functions interdependently, so that the possible inefficiency of the identified system does not compromise the process as a whole.

In this context, as described by Goldratt (2003), all efforts to manage processes, according to the precepts of the theory of restrictions, must comply with a five-step methodology to focus on the continuous improvement in the capacities required by the system aiming at global gain.

\section{METHODOLOGY}

This is a bibliographical research, which consists in the examination of the scientific literature for the survey and analysis of what has already been produced on a given theme. The bibliographical research according to Cervo and Bervian (1983, p.55), is the one that "explains a problem from theoretical references published in documents".

In this sense, it is possible to observe that when the study refers to a bibliographical research, based on this research should then present a result for the analyzed situation, contributing to its area of activity. Thus, the study was developed in a Public Institution in the area of Education.

The following were used as a source of information and inclusion criteria in the study: articles indexed in spell platforms - Scientific Periodicals Electronic Library, SciELO Scientific Electronic Library Online, and google scholar, from January 2000 to May 2019; identifying in this period, the proposals and trends on the theme theory of restrictions in public and private organizations. In addition, the term "theory of restrictions" was used to carry out the research as a descriptor.

First, a bibliographic review was made, through a survey on the Spell platform, in which 24 (twenty-four) references were identified using the keyword "theory of restrictions". In order to increase the number of references, a review was made on the Scielo and Google Scholar platform, where 7 (seven) articles and 4 (four) articles were found, respectively. Data tabulation was performed through the SPSS program, which is a software that allows statistical analysis of data and then tabulated in an Excel spreadsheet.

Data analysis was performed by segregating the following data: classification of articles by year; number of authors per article; authors with a higher number of articles in the sample 
DOI: 10.14807/ijmp.v12i4.1396

analyzed; articles related to public organizations and classifies qualis capes of the journals. That said, we analyzed all the articles found, in which two (2) of them were related to the application of TOC in public organizations, and the others dealt with the application of TOC in the private sector.

The categories were established before the field work, in the exploratory phase, which is pertinent, because according to Minayo (1996), the researcher can define the categories to be investigated before the field work and after data collection, he can also reformulate them aiming at the classification of the data found in his field work.

\section{PRESENTATION AND DISCUSSION OF RESULTS}

The Spell, Scielo and Google Scholar platform, respectively, published in the years 2000-2019, 35 (thirty-five) articles referring to the theme "theory of restrictions". According to the descriptors determined in the methodology, Figure 1 demonstrates the distribution of publications in the periods analyzed per year.

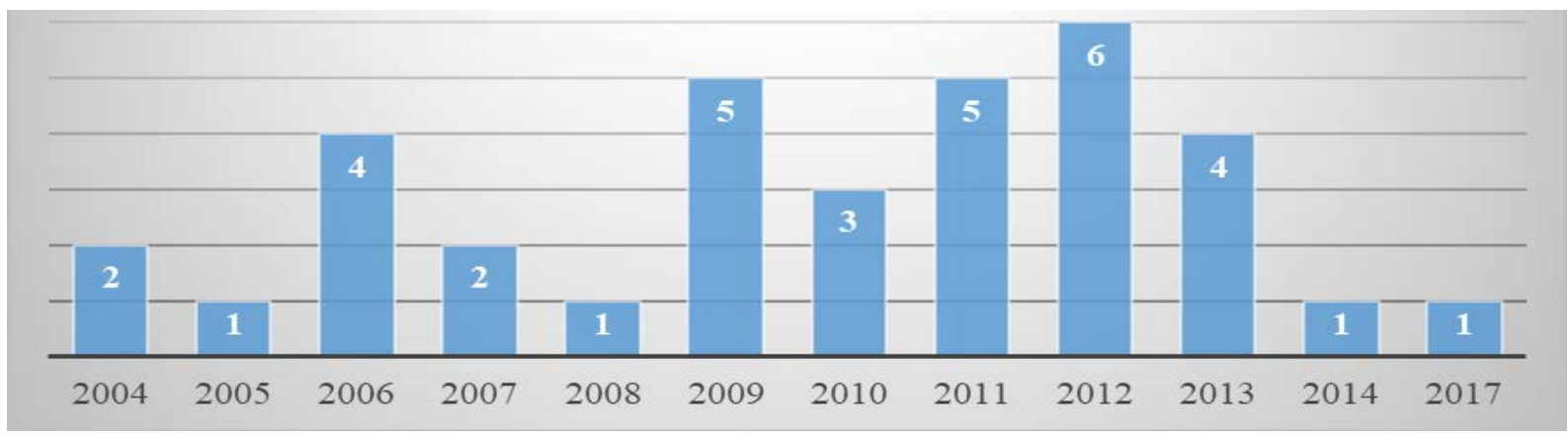

Figure 1: Distribution of articles by year surveyed

Source: Prepared by the authors based on the research

Figure 1 shows that the first publications on the theme theory of restrictions took place in 2004, with (2) two publications. In 2012, it was the period with the highest incidence of publications (13). As the theory of restrictions focuses on application in the industrial sector, which considers the need to identify the restriction in production processes, the main researches were concentrated in private companies, focusing on the identification of production bottlenecks, in order to improve their profitability.

Once the bottleneck is identified, it should be occupied all the time of its availability (Rodrigues \& Peixoto, 2015), causing the restricted resource to be used at its maximum capacity. This decision is important because a lost hour in the bottleneck is a lost hour in the entire system (Goldratt \& Cox, 1990). The two studies that were applied in the public sector were conducted in 2006.

Table 1 shows the authors who had the highest number of publications on the subject. 
INDEPENDENT JOURNAL OF MANAGEMENT \& PRODUCTION (IJM\&P)

http://www.ijmp.jor.br

v. 12, n. 4, May-June 2021

ISSN: 2236-269X

DOI: $10.14807 /$ ijmp.v12i4.1396

Table 1: Authors with the highest number of articles in the sample analyzed

\begin{tabular}{l|c|l}
\hline Authors & Publications & Institution to which it belongs \\
\hline Samuel Cogan & 9 & Federal University of Rio de Janeiro \\
\hline Daniel Pacheco Lacerda & 4 & University of Vale do Rio dos Sinos \\
\hline Luis Henrique Rodrigues & 3 & Federal University of Rio Grande do Sul \\
\hline Anderson Chaves da Silva & 2 & Federal University of Rio de Janeiro \\
\hline Carlos Alexandre Nascimento Wanderley & 2 & Federal University of Rio de Janeiro \\
\hline Júlio César Bastos de Figueiredo & 2 & University of São Paulo \\
\hline Rodrigo Santana de Almeida & 2 & Federal University of Rio de Janeiro \\
\hline Other & 107 & - \\
\hline
\end{tabular}

Source: Prepared by the authors based on the research

Table 1, among the authors who published the most on the theme theory of restrictions, stands out Samuel Cogan, Professor in graduate studies - MBA in business finance at the Faculty of Administration and Accounting Sciences - UFRJ/FACC, who, in addition to the localized articles, also carried out the orientation of papers, presentation of seminars and congresses containing the methodology of the theory of restrictions.

Prof. Dr. Daniel Pacheco Lacerda, Coordinator of the Bachelor's Degree in Production Engineering/UNISINOS, in addition to the identified publications, taught disciplines related to the theory of restrictions in supply chains, and has the methodology of restriction as one of his lines of research, in addition to participation in meetings, congresses, stalls and orientations of graduation and master's degree. The author taught a course of "advanced training in the themes toyota production system, theory of constraints, systemic thinking and innovation in 2013".

Prof. Dr. Luis Henrique Rodrigues, professor at the University of Vale do Rio dos Sinos, in addition to publications located on the platforms, since 1998 has been publishing papers with the researched methodology: theory of restrictions - An analysis of the actions of improvements necessary to lift the capacity of the restrictions. Soon after in table 2 , the journals that had the highest frequency of publications during the research period are presented.

Table 2: Ranking of journals by frequency of publications

\begin{tabular}{l|c|c}
\hline Journals & Publications & Frequency \\
\hline Gestão \& Produção (UFSCAR. Printed) & 5 & $14,29 \%$ \\
\hline Produção Online (São Paulo Printed) & 2 & $5,71 \%$ \\
\hline Revista de Administração da Unimep & 2 & $5,71 \%$ \\
\hline Revista de Administração Mackenzie & 2 & $5,71 \%$ \\
\hline Other & 24 & $68,58 \%$ \\
\hline
\end{tabular}

Source: Prepared by the authors based on the research

In table 2, we can observe that the journal Management \& Production presented the largest number of publications on the theme theory of restrictions, the journal has a continuous flow of quarterly publications published by the department of production engineering (DEP) of the Federal University of São Carlos (UFSCar). Its mission is to be a means of dissemination of original works and that present important scientific research and results for the areas of 
DOI: $10.14807 /$ ijmp.v12i4.1396

Administration and Production Engineering, through empirical, theoretical and simulation studies.

Then, three journals appear that had two publications each on the subject. The Online Production Magazine, a journal of ABEPRO, which aims to qualify and give ample visibility to the scientific production of the area of Production Engineering and related areas. Unimep's Management Journal, whose mission is to contribute to the improvement and dissemination of knowledge in Business Administration through the publication of research papers, theoretical analyses and reviews. Finally, we have the Mackenzie Management Journal, whose mission is to contribute to the excellence of academic activities in the area of knowledge of business administration and to the development of administrative action in organizations, through dissemination of scientific research papers in the form of theoretical development articles and unpublished theoretical-empirical articles, quality and generating new knowledge in the field, with significant magnitude of contribution.

The other journals presented only one publication in the analyzed period. Next, table 3 presents the qualis capes classification of each journal.

Table 3: Classification qualis capes of the journals that published on the subject

\begin{tabular}{c|c|c}
\hline Qualis journals & Quantities & Frequency \\
\hline A2 & 6 & $17,15 \%$ \\
\hline B1 & 12 & $34,28 \%$ \\
\hline B2 & 14 & $40,00 \%$ \\
\hline B3 & 3 & $8,57 \%$ \\
\hline
\end{tabular}

Source: Prepared by the authors based on the research

Table 3 presents the qualis of the journals that published on the subject, which is the set of procedures used by Capes to stratify the quality of intellectual production. Thus, they are classified from A1 to C, where classification A represents a better stratum. In the articles analyzed, $17.15 \%$ (6) were published in journals with A2 classification, demonstrating the quality of the researches performed. It is noted that a large majority of publications were carried out in journals with classification B, being $40 \%$ of the publications (14), carried out in journals classified as B2.

Figure 2 shows the word cloud, which represents the keywords, used in the 35 articles identified in the search. To perform the figure was used the program jasondavies, which demonstrates the degree of frequency of each keyword used, those words that appear more clearly in the figure are the ones that were used more often. In this context, the words "theory" and "restrictions" are the ones that appear most frequently in published articles. Following the words "process", "reality", "improvement", "production" also appear with some frequency. 
DOI: 10.14807/ijmp.v12i4.1396

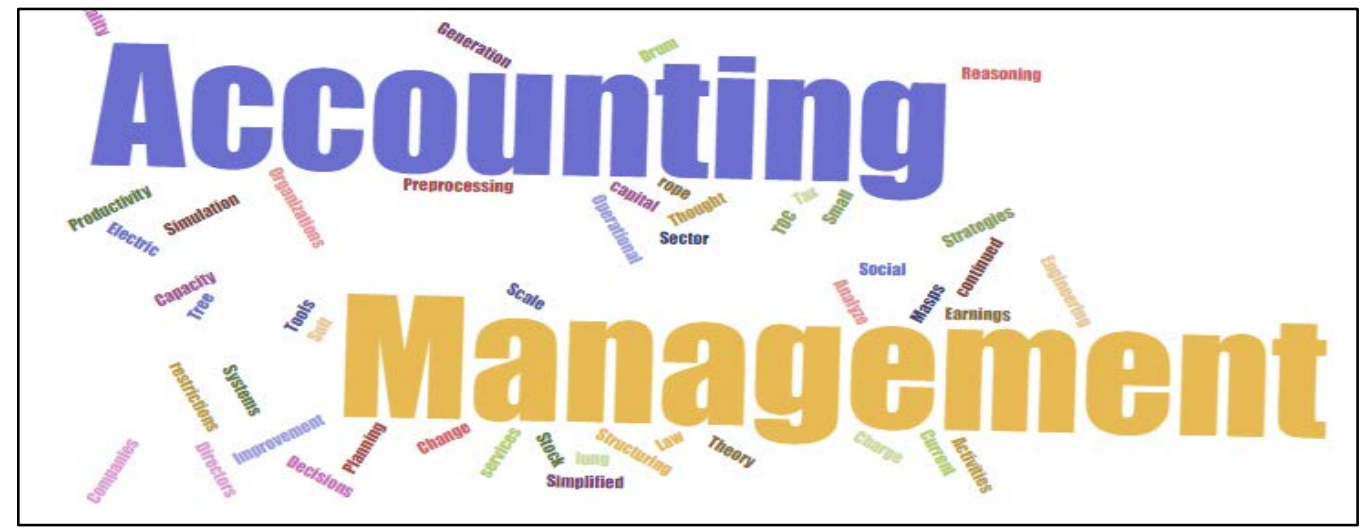

Figura 2: Nuvem de palavras

Fonte: Elaborado pelos autores com base na pesquisa

After analyzing the information identified in the bibliographical research, about the publications on the subject and its applicability in public and private organizations, in the next chapter an analysis of the publications related to the application of TOC in the public sector will be carried out.

\subsection{Cases of Application of the Theory of Restrictions in Public Organizations}

After identifying the studies that deal with the application of the theory of restrictions in public organizations, we set out to perform an analysis of the two cases, in order to demonstrate the operationalization of the application of TOC. The first article is titled "Restriction Management in Public Health Organizations: A Process of Continuous Improvement" and its authors are: Sabbadini, Gonçalves and Oliveira, (2006). This study points to the deficit of publications in the health area and presents the use of TOC in the cancer treatment center of the National Cancer Institute (INCA) and in a hospital emergency unit.

As main results, there was a productivity gain in the direction of the organization's goal, thus enabling a greater number of cases of emergency patients to be attended, while improving the quality of care to them. The experiments carried out allowed anticipating consequences of operational changes before its implementation in the real system, without generating high burdens, in a complex sector, with high costs and high risks, as is a hospital emergency unit, which involves the care of human lives.

The second article is titled "The Contribution of the Theory of Restrictions to the Purchasing Process of The Brazilian Army Military Organizations" and its author is: Luchi (2006). Through an exploratory research, the author describes that the application of TOC can contribute to various processes of military organizations and also made use of the process of 
DOI: 10.14807/ijmp.v12i4.1396

focusing on the five steps of the theory of restrictions, applied in the procurement process of military organizations.

In the application of the five steps of the TOC, it was identified that the restriction was concentrated in the bidding phase and, soon after, it was explored, in order to define the improvements, suggesting the preparation of bidding notices every two weeks, consolidating their demands and sequence of own calendar of activities, without the interruption of the members for other activities and with computer equipment with their proper capacity of use.

Subsequently, the pre-bidding phases were adjusted for adjustment throughout the process. In this article, the need for its own analysis was reiterated, since each organization has its characteristics. The application of the theory of restrictions provided a better efficiency in the realization of the process of purchase of the military organization, object of the study.

The two cases presented, despite representing a small universe in relation to the total number of publications dealing with the application of the theory of restrictions in private and public sectors, show that the application of the five steps of TOC in the public sector brought benefits to the institutions that applied the concepts of theory, bringing financial gains after its application.

\subsection{Application of the five steps of TOC in a Public Organization of the Area of Education}

According to the application of the theory of restrictions in a public organization in the area of education, the observation of the process of cooperation agreements was carried out. The need for speed in this process was identified, as it directly contributes to the development of teaching, research and extension activities, in addition to the mutual contribution to cooperative companies.

In this sense, the process of cooperation agreements begins with the manifestation of the institution or company concerned and, after that, each project/agreement must have a coordinator. This coordination remains responsible for contact, survey of legal documentation, analysis and verification of forms related to the companies involved. After receiving all documentation and filling out forms, it is necessary to prepare the draft and activity plan of said contract and, having the agreement of all participants, the next phase is the signatures for the realization of the agreement.

According to the process described, the following phases of the five-step focus process of the theory of constraints, presented in Chart 1 , were applied. 
DOI: 10.14807/ijmp.v12i4.1396

Chart 1: Five steps theory of constraints.

\begin{tabular}{|c|c|}
\hline Steps & Procedures \\
\hline $1^{\circ}$ Restriction Identification & $\begin{array}{l}\text { The first stage of the Five-Step Focus Process is to identify the restriction } \\
\text { in the Cooperation Agreements process, at this stage it was identified that } \\
\text { the restriction in the process is presented by the delay of the Project } \\
\text { Coordinator when receiving the necessary documents and preparation of } \\
\text { other relevant forms. In addition, it was identified that the other phases } \\
\text { do not consume a large amount of time, thus concentrating all the } \\
\text { restriction on a given activity. It is observed that in the process the } \\
\text { restriction is presented by the difficulty of focusing on the survey, filling } \\
\text { and analysis of documents for the elaboration of the process. }\end{array}$ \\
\hline $\begin{array}{l}2^{\circ} \text { Decision on How to Exploit } \\
\text { Restriction }\end{array}$ & $\begin{array}{l}\text { The second stage of the Five-Step Focus Process is based on the } \\
\text { exploration of the restriction to the maximum in the process, there was } \\
\text { the pending of numerous cooperation agreements without finalization, in } \\
\text { this sense there is a great importance for the entity to sign Cooperation } \\
\text { Agreements, since the development occurs in a mutual way for all } \\
\text { participants. First to meet this demand, the verification and availability } \\
\text { of the agreement server was performed to be responsible for the request } \\
\text { and analysis of documentation, preparation of reports, drafts, and, } \\
\text { establishment of the process in the electronic platform, making the } \\
\text { Agreement available only for the final phase and signature of the legal } \\
\text { representatives of the organization, together with the Project } \\
\text { Coordinator. }\end{array}$ \\
\hline $\begin{array}{l}3^{\circ} \text { Subordination of All Other } \\
\text { Restrictions }\end{array}$ & $\begin{array}{l}\text { The third stage of the Five-Step Focusing Process presents the } \\
\text { subordination of the other phases of the process to the restrictive phase, } \\
\text { that is, working together with the other phases so that the restriction does } \\
\text { not occur again, so that the entire week will be sent to the Coordinator } \\
\text { along with the entire Unit Direction, if there is any pending } \\
\text { documentation related to the agreements. After, the documentation phase } \\
\text { will always be instigated and regularized by the process people, so all } \\
\text { phases are subject to restriction. }\end{array}$ \\
\hline $4^{\circ}$ Elevation of Restriction & $\begin{array}{l}\text { The fourth step of the Five-Step Focus Process is to increase the capacity } \\
\text { of the constraint. The elevation in this phase was performed by the } \\
\text { adoption of systematization, since previously the process did not present } \\
\text { electronic and integrated phases. The current process is being satisfactory } \\
\text { in the Unit, with no need for elevation, even though the sequence of the } \\
\text { process and its completion is performed in the Matrix Unit. Thus, the } \\
\text { fourth stage of the Five-Step Focusing Process is considered fulfilled. }\end{array}$ \\
\hline $5^{\circ}$ Return to The First Stage & $\begin{array}{l}\text { The fifth stage of the Five-Step Focus Process consists of verifying the } \\
\text { phase of the process in which a new restriction begins in the speed of the } \\
\text { cooperation agreement process. Thus, it was found that there are } \\
\text { improvements in the process, and the speed is being maintained } \\
\text { efficiently because it is only influenced in its capacity by external factors } \\
\text { to the Unit. }\end{array}$ \\
\hline
\end{tabular}

Source: Prepared by the authors based on the research

After applying the five stages of the theory of restrictions in the entity, it is observed that the stage of the process that presented restriction was the phase of survey of the legal documentation analysis and preparation of contracts, which presented excess time spent to release these contracts, which was identified as the bottleneck of the process.

To remedy the problem, initially it was verified with the server responsible for the contracts of agreements the availability for the execution of the activity of survey, analysis and realization of cooperation agreements, which would no longer be under the conduct of the 
DOI: 10.14807/ijmp.v12i4.1396

coordinator of the agreement. After the acceptance of the server, the process that was previously carried out in physical format, began to be carried out on an electronic platform, providing more speed to the process and, finally, would be available for analysis and signature of the coordinator and managers.

In the course of the steps of the theory, it is analyzed that, after the application of the four previous steps, there is no need to return to the first stage, because the solution of the bottleneck in the process was performed efficiently, contributing to the agility of the activities.

\section{FINAL CONSIDERATIONS}

The present study aimed to verify the applicability of the five steps of the theory of restrictions as an alternative to process efficiency, assisting public management in solving these problems.

Management based on the theory of constraints takes on a strategic dimension in a complex environment that is the public sector. Your main challenge is to permanently manage resources. By redirecting the actions of improvement in the processes performed and, after, identifying the bottlenecks, one can adjust the capacity to demand and act at the points of the system where the benefits of the change will have repercussion on the increase in the capacity of the exercise of activities at a specific point in the sector, improving the overall performance of the entity.

The application of bibliographic research identified thirty-five publications in the researched platforms, in which only two deal with the application of the theory of restrictions in the public sector. The results presented by the two public institutions show us that management based on the theory of constraints is able to identify bottlenecks in the processes performed and, at the same time, allows managers to resize the actions of improvements to meet the demands that these entities have, in an agile way, enabling time gain and greater efficiency of the processes.

On the other hand, the "practical" application of the five steps of the theory of restrictions in a public agency in the area of education, showed that the bottleneck in the process was the excess of time spent to carry out the activity of surveying the legal documentation, analysis and drafting of contracts. To solve this bottleneck, it was possible to verify the availability of the server responsible for the contracts of agreements to include in its activities the realization of cooperation agreements and, also, the change of the physical format of documents to the electronic format, contributing to the efficiency of the process. 
DOI: $10.14807 /$ ijmp.v12i4.1396

As main results of the research, the feasibility and importance of the application of the tool is ratified, directly impacting on the efficiency and maximization of quality in the services offered to society and optimizing public resources, which may be applied in other sectors of our society. With the efficiency in achieving the applicability of the five steps of the theory of restrictions, the management and identification of the bottleneck in the process of cooperation agreements contributed to the speed in the public service.

As limitations of the study, it is noteworthy that bibliographic research focused on scientific publications classified as articles in national journals, not including the analysis of international studies on the subject.

For future research it is suggested that more studies be carried out in the public area in order to apply the theory of restrictions in other services offered, because, in this way, it is possible to find alternatives for process improvements and efficient results in public management.

\section{REFERENCES}

Bornia, A. C. B. (2010). Análise Gerencial de Custos: Aplicação em empresas Modernas. 3 ed. São Paulo: Atlas.

Cervo, A. L. C., \& Bervian P. A. B. (1983). Metodologia científica: para uso dos estudantes universitários. São Paulo: McGraw-Hill do Brasil.

Conselho Federal de Contabilidade. (2013). Normas Brasileiras de Contabilidade NBC 16. Recuperado de http://portalcfc.org.br/wordpress/wpcontent/uploads/2013/11/setor_publico.pdf.

Cox, J. F. C., \& Schleier, J. G. S. (2013). Handbook da Teroria das Restrições. 1 ed. Porto Alegre: Bookman.

Fontoura, F. B. B. (2013). Gestão de custos. Uma visão integradora e prática dos métodos de custeio. São Paulo: Atlas.

Fontoura, F. B. B., \& Pozzebon, J. P. (2016). Planejamento de Resultado através da Margem Restritiva integrada com o método UEP. Estudos Acadêmicos em

Administração, Contábeis, Economia e Relações Internacionais, 2, 214-230.

Gibbon, A. R. O., Gonçalves, T. L., \& Rodrigues, J. M. (2008). Teoria das Restrições: Um estudo de caso em uma empresa de prestação de serviço de limpeza. $2^{\circ}$ Congresso UFSC de Controladoria e Finanças

Gil, A. C. G. (2010). Como elaborar projetos de pesquisa. 5 ed. São Paulo: Atlas, p. 184.

Gil, A. C. G. (1999). Métodos e técnicas de pesquisa social. 5 ed. São Paulo: Atlas.

Goldratt, E. G., \& Cox, J. F. C. (2003). A Meta: um processo de melhoria contínua. 2 ed. São Paulo: Nobel.

Goldratt, E. M., \& Cox, J. (1993). A meta: um processo de aprimoramento contínuo. 7 ed. São Paulo: Educator, 318 p. 
Goldratt, E. G., \& Cox, J. F. C. (1990). A Meta. 4 ed. São Paulo: Imam.

Kohama, H. K. (2014). Contabilidade Pública. Teoria e Pratica. São Paulo: Atlas.

Lei No 4.320, de 17 de Março de 1964. (1964). Estatui Normas Gerais de Direito

Financeiro para elaboração e controle dos orçamentos e balanços da União, dos Estados, dos Municípios e do Distrito Federal. Recuperado de http://www.planalto.gov.br/ccivil_03/leis/14320.htm.

Luchi, O. L. (2006). A Contribuição da Teoria das Restrições para o Processo de Compras das Organizações Militares do Exército Brasileiro. Encontro Nacional dos Programas de Pós-Graduação em Administração, Salvador, BA, Brasil.

Minayo, M. C. S. M. (2001). Pesquisa social: teoria, método e criatividade. Petrópolis: Vozes.

Minayo, M. C. S. M. (org.). (1996). Pesquisa Social: teoria, método e criatividade. 6 ed. Petrópolis (RJ) : Vozes.

Noreen, E. N., Smith, D. S., \& Mackey, J. T. M. (1996) A teoria das restrições e suas implicações na contabilidade gerencial: um relatório independente. São Paulo: Educator.

Rodrigues, M. R. O. R., \& Peixoto, J. K. C. (2015). Teoria das restrições como uma ferramenta de análise e solução de problemas: um estudo de caso em uma confecção na cidade de limoeiro do norte-ce. XXXV Encontro Nacional de Engenharia de Produção, Fortaleza, CE.

Sabbadini, F. S. S., Gonçalves, A. A., \& Oliveira M. J. F. O. (2006). Gerenciamento de Restrições em Hospitais de Emergência: Um Processo de Melhoria Contínua. Encontro de Administração Pública e Governaça, São Paulo, SP, Brasil.

Sipper, D., \& Bulfin, R. L. Production: planning, control, and integration, 1997. 